\title{
Use of Correlations for PVT Characteristics of Drilling Fluids in Kick Analysis
}

\author{
Levi A. G. Farias*, Nara A. Policarpo, Nilo R. Kim, Paulo R. Ribeiro, Andre T. Piza Falcade
}

\begin{abstract}
This present work aims at finding thermodynamics properties of drilling fluids and gas reservoir mixtures to apply in kick simulators. It was adjusted the oil formation volume factor for a methane/ester emulsion mixture at temperatures between 70 and $130^{\circ} \mathrm{C}$. The results showed a good agreement between the experimental and calculated values.
\end{abstract}

Key words: Kick, Drilling Fluids, Well Control.

\section{Introduction}

The study of drilling fluids represents an important field in Petroleum Engineering, particularly when it comes to the exploration of oil fields, that require a special attention to assure the safety of the drilling well, especially to avoid the phenomenon of blowouts. The correct selection of the drilling fluids, which have the function of cleaning and cooling the drilling bit, carrying cuttings produced in the drilling activities, and maintaining the wellbore secure and stable, contribute to achieving the mentioned purpose of kick detection ${ }^{1}$. Although, collecting information about the properties of those fluids may be costly and overly complex and, therefore, the use of correlations as a function of pressure, temperature and volume can facilitate the study and the progress of this study area, generating compelling results for derived properties such as solubility, compressibility, viscosity, bubble point, density, and formation volume factor of the fluid ${ }^{2}$. Hence, the present work aims at the correlations adjustment of the mentioned properties using experimental data to be after used in kick simulators.

\section{Results and Discussion}

To help the early prediction of kick events, correlations of thermodynamic properties are adjusted to be after implemented in kick simulators. Such correlations meet the experimental data usually measured in a PVT (Pressure-Volume-Temperature) cell. In this present work, experimental data of the oil formation volume factor $\left(B_{m}\right)$ for a methane/ester emulsion mixture, composed by ester/brine emulsion in a ratio of $60-40 \%$ in volume, from a previous work ${ }^{3}$ was used to adjust a polynomial model by using the software LabFit®. Using an equation as a function of gas molar fraction $\left(f_{\mathrm{g}}\right)$ and pressure $(\mathrm{P}), \mathrm{B}_{\mathrm{m}}$ was adjusted at temperatures of $70,90,110$, and $130^{\circ} \mathrm{C}$, as can be seen in Equation 1.

$$
\mathrm{B}=\mathrm{a} \cdot f_{\mathrm{g}}{ }^{5}+\mathrm{b} \cdot f_{\mathrm{g}}^{4}+\mathrm{c} \cdot f_{\mathrm{g}}{ }^{3}+\mathrm{d} \cdot f_{\mathrm{g}}{ }^{2}+\mathrm{e} \cdot f_{\mathrm{g}}+f \cdot f_{\mathrm{g}} \cdot \mathrm{P}+\mathrm{g} \cdot \mathrm{P}+\mathrm{h}
$$

The parameters adjusted for $\mathrm{B}_{\mathrm{m}}$ equation are shown in Chart 1. These equations are valid for pressures ranging from 0 to $103 \mathrm{MPa}$, which differ from equations obtained by $\mathrm{Kim}^{3}$, that adjusted two equations by each pressure range, low $(\mathrm{P}<35 \mathrm{MPa})$ and high $(35<\mathrm{P}<103 \mathrm{MPa})$ pressure. Image 1 shows the comparison between experimental data obtained from $\mathrm{Kim}^{3}$ and those found by the adjusted correlation. The values of the mean absolute error (MAE) of the correlation were lower than $0.5 \%$ for all studied temperatures, as shown in Chart 1.

Chart 1. Parameters adjusted for $B_{m}$

\begin{tabular}{|l|c|c|c|c|}
\hline Coeff. & $\mathrm{T}=70^{\circ} \mathrm{C}$ & $\mathrm{T}=90^{\circ} \mathrm{C}$ & $\mathrm{T}=110^{\circ} \mathrm{C}$ & $\mathrm{T}=130^{\circ} \mathrm{C}$ \\
\hline $\mathrm{a}$ & $6,53 \times 10^{-9}$ & $6,21 \times 10^{-9}$ & $7,68 \times 10^{-9}$ & $6,65 \times 10^{-9}$ \\
\hline b & $-1,51 \times 10^{-6}$ & $-1,42 \times 10^{-6}$ & $-1,78 \times 10^{-6}$ & $-1,52 \times 10^{-6}$ \\
\hline c & $1,24 \times 10^{-4}$ & $1,16 \times 10^{-4}$ & $1,47 \times 10^{-4}$ & $1,24 \times 10^{-4}$ \\
\hline d & $-4,13 \times 10^{-3}$ & $-3,80 \times 10^{-3}$ & $-4,86 \times 10^{-3}$ & $-4,06 \times 10^{-3}$ \\
\hline e & $4,37 \times 10^{-2}$ & $3,93 \times 10^{-2}$ & $5,01 \times 10^{-2}$ & $4,21 \times 10^{-2}$ \\
\hline f & $-6,93 \times 10^{-6}$ & $-9,06 \times 10^{-6}$ & $-9,70 \times 10^{-6}$ & $-1,37 \times 10^{-5}$ \\
\hline g & $-7,20 \times 10^{-4}$ & $-6,54 \times 10^{-4}$ & $-7,08 \times 10^{-4}$ & $-7,31 \times 10^{-4}$ \\
\hline h & 1,027 & 1,045 & 1,062 & 1,077 \\
\hline MAE (\%) & 0.182 & 0.187 & 0.139 & 0.336 \\
\hline
\end{tabular}

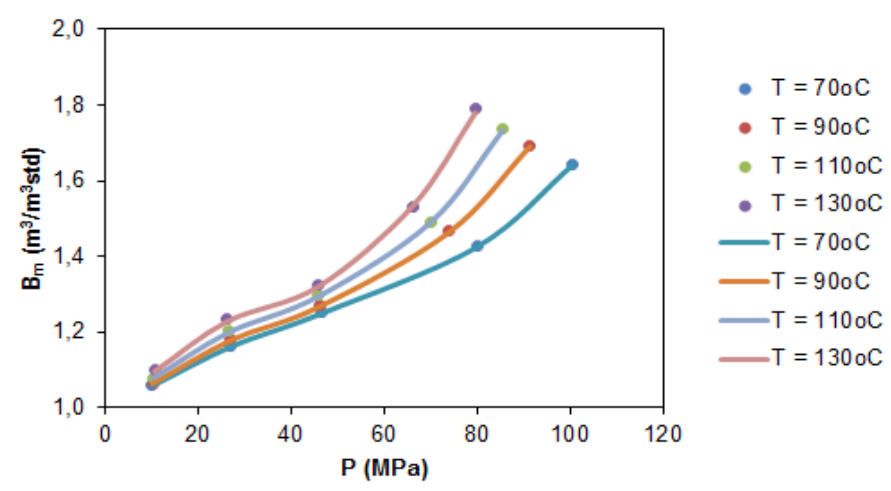

Image 1. $B_{m}$ values - experimental ${ }^{3}$ and adjusted.

\section{Conclusions}

The correlation adjusted from experimental data for the oil formation volume factor is reliable due to the very low mean absolute errors ( $<0.5 \%$ ) observed for the studied conditions. This correlation can be applied in kick simulators modeling accurately.

\section{Acknowledgement}

The authors are thankful for Petrobras financial support.

\footnotetext{
${ }^{1}$ Thomas, J. E. (Org.). Fundamentos de Engenharia de Petróleo. Rio de Janeiro: Interciência, Petrobras, 2001. 271p.

${ }^{2}$ Monteiro, E. N.; Ribeiro, P. R. and Lomba, R. F. T. SPE Drilling \& Completion 2010, 25, 45-52.

${ }^{3}$ Kim, N. R. Estudo do comportamento PVT de misturas de metano e fluidos de perfuração base éster. Tese. FEM, Unicamp, 2010.
} 